\title{
After Liberal Global Democracy: New Methodology for New Praxis
}

\author{
Jan Aart Scholte ${ }^{1,2}$
}

Received: 5 January 2019 / Accepted: 4 May 2019 / Published online: 18 May 2019

(C) The Author(s) 2019

\begin{abstract}
Liberalism is in trouble as a normative basis of world order, partly for its failure to deliver adequate democracy to contemporary globalisation. This article explores how new ideas and practices of democracy might underpin a future post-liberal world order. The discussion especially addresses methodological issues, on the premise that the way that global democracy is studied deeply affects the ways that it can be understood and enacted. To open space for more innovative thinking about people's power in a global world, the article develops an approach which-in contrast to established liberal theorising-emphasises principles of diversity, reflexivity, and praxis. Drawing on experiences of implementing these principles in a six-year 'Building Global Democracy' programme, the article argues that such a methodology can generate different, imaginative and transformative notions. In particular, post-liberal reinventions of democracy could redefine the demos, incorporate nonmodern institutions, deepen justice, and confront structural power hierarchies. To be sure, as the final section reflects, the formulation and implementation of post-liberal constructions of global democracy face considerable challenges. Yet, with no less than the future of a good society at stake, it is vital further to pursue such experiments in globality beyond liberalism.
\end{abstract}

Keywords Democracy · Global democracy · Globalization · Anti-globalization · Liberalism $\cdot$ Neoliberalism

\section{Jan Aart Scholte}

jan.scholte@globalstudies.gu.se

1 School of Global Studies, University of Gothenburg, Gothenburg, Sweden

2 Centre for Global Cooperation Research, University of Duisburg-Essen, Duisburg, Germany 


\section{Introduction}

Liberal world order is in trouble today. After a century-long steady, if irregular, ascent to peak in the early 1990s, this normative frame for world politics now once again faces deep challenges. Liberal principles seemed bound for a final triumph with the end of the Cold War. Proponents celebrated the apparent victory of an open international economy, universal human rights, representative governments advancing worldwide, and peaceful settlement of disputes through international law and multilateral institutions. But the touted 'end of history' (Fukuyama 1992) was but fleeting.

Already the late 1990s saw an upsurge of 'anti-globalization' activism against 'neoliberalism', especially directed at the main multilateral economic institutions (IMF, OECD, WTO, World Bank). This resistance was seemingly contained after the early 2000s with reformist prescriptions of corporate social responsibility, good governance, sustainable development, gender mainstreaming, and the like. Yet the respite proved temporary, with first the Occupy movement in 2011-12 and now an apparently stronger wave of opposition to global liberalism in the late 2010s. Whereas the earlier backlashes had mainly left-progressive expressions, the current reaction has a primarily conservative-nationalist-authoritarian character. Moreover, this time antiglobalism has captured several major states, including most notably the presidency of the former main sponsor of a liberal world order, the USA. To the extent that reformist global visions persist, their centre of gravity may have moved to the so-called 'emerging powers', with steps like China's Belt and Road Initiative which also depart from liberal Pax Americana.

Possibly the present counter-movements pass as well, and West-centric liberalism makes another comeback; yet it is also quite plausible that this normative basis of world order confronts long-term decline. Significant streams of society and politics across the planet (including in the emerging powers) perceive that liberal principles of open economy, representative government, human rights, and multilateralism have failed to deliver on their promises of the good life. In addition, many critics believe that a liberal world order does not (sufficiently) address issues of cultural identity, distributive justice, ecological integrity, moral decency, and solidarity. Given the breadth and depth of the scepticism towards (neo)liberalism, it is by no means clear that another round of 'social market' reforms such as multistakeholder initiatives and the Sustainable Development Goals (SDGs) can succeed to resuscitate a liberal world order for the 2020s and beyond. In this situation of flux and unpredictability, it seems vital to prepare for possible post-liberal world orders with new normative visions.

At present, most alternatives to liberalism on offer reject globality and look inwards. Some are localist initiatives with progressive intentions, such as food sovereignty movements and alternative currency schemes. Other anti-liberal reactions involve conservative nationalism, as in Bolsonaro's Brazil, Modi's India, Duterte's Philippines, Putin's Russia, Erdogan's Turkey, and Trump's USA. Xi Jinping's China promotes an uneasy mix of (readily contradictory) global orientation and sovereigntism. Further movements are unabashedly xenophobic, including various 
ultranationalist parties and several religious fundamentalisms. Yet, for all their diversity across a left-right spectrum, these anti-liberal programmes share a quality of retreating from globalisation. The Chinese government vision partly excepted, each assumes that a global world must of necessity be liberal-and thus culturally imperialist, ecologically destructive, economically insecure, socially unequal, and politically elitist.

Yet herein lies a core dilemma: de-globalising strategies are impracticable, however attractive or unattractive their visions might be. For better or worse, contemporary social relations are deeply-and for the foreseeable future irrevocablyglobalised. Climate change, biodiversity, natural resource depletion, and other ecological challenges have intrinsic significant global dimensions. An unavoidable global quality also marks today's digital communications, financial flows, health problems, production processes, and weapons technologies. Moreover, globality underpins various identities that countless people hold dear: so, for example, diasporas, faiths, professions, and various other communities are not territorially bounded. In short, alternatives to a liberal world order must address large degrees of global connectivity. Retreats to localism, nationalism, and sovereigntism are not viable.

The present article pursues an experiment that combines anti-liberalism and pro-globalism. In other words, it seeks to imagine a post-liberal world order that is still globally oriented. In particular, the exercise contemplates post-liberal global democracy: i.e. a reconstruction of 'people's power' that could provide meaningful collective self-determination in future globalised society. This emphasis on democracy does not deny the importance of other values. Indeed, a successful global-scale democracy would need also to bring cultural respect, ecological care, economic welfare, and so on. Still, a focus on global democracy is warranted inasmuch as many of today's attacks on liberal world order take particular aim at the undemocratic character of existing global governance. Thus, a post-liberal normative design which neglects global democracy would be incomplete.

To work towards this post-liberal global democracy, the rest of this article proceeds in six steps. First, the next section outlines today's challenge of global democracy. The third section reviews existing literature on global democracy and finds this work to be significantly constrained by liberal imagination. To open space for wider innovative thinking, the fourth section introduces principles of diversity, reflexivity, and praxis as cornerstones of an alternative methodology for global democracy research. The fifth section describes the application of these principles through a socalled Building Global Democracy (BGD) programme in 2008-2014. The sixth section indicates how, with this alternative methodology, the BGD initiative generated novel thinking about democracy for a post-liberal world order. The seventh and concluding section reflects on challenges in taking forward this transformative agenda.

\section{Global Democracy: The Problem in Brief}

An initial step in this experiment is to specify the problem: why is it necessary to contemplate global democracy? The following paragraphs first identify key generic features of democracy and then note that the ways in which democracy is practised 
have shifted over time. In today's society, globalisation presents the kind of transformation that can stimulate reinventions of democracy, perhaps in the process transcending the liberal model of democracy that has reigned supreme in modern history.

Democracy is understood here in a generic sense from its Greek roots demos ('people') and kratos ('power') to mean 'people's power'. With democracy, a human collectivity jointly shapes the conditions of its coexistence. All affected people have due participation in, and control over, the decisions that govern their common circumstance and destiny.

Note that, in being generic, this conception does not limit democracy to one or the other historically and culturally specific way of enacting 'people's power'. The hegemony of liberalism in the modern political imagination tends to present democracy as being equivalent to periodic multi-party elections to representative governmental institutions, coupled with guarantees of individual liberty and a vibrant civil society. Such practices are by no means per se bad: on the contrary, liberal democracy may in certain contexts substantially promote human flourishing in a good society. The point to emphasise here is merely that liberal democracy is not the definition of democracy itself. Across time and place, societies have found many different ways to pursue 'people's power'. Democracy is not intrinsically liberal.

This historical contingency of democratic practices wants particular emphasis in current times of accelerated globalisation. Society today involves unprecedented transplanetary social connectivity, where interactions and interdependencies among people play out substantially within earth-wide arenas (Scholte 2005). Planetary domains figure importantly in flows of communications, disease, knowledge, merchandise, money, people, pollutants, and violence. Indeed, contemporary minds generally conceive of 'the world' as 'the globe'.

What does this globalisation imply for democracy? After all, prevailing theories and practices of people's power have centred on the country-nation-state. Modern constructions of democracy have assumed: (a) the geographical setting of a bounded territory; (b) the cultural setting of a national community; and (c) the political setting of a sovereign government. Contemporary globalisation has seriously disrupted this formula. Geographically, many social relations are now transboundary. Culturally, a variety of nonterritorial attachments (e.g. age, class, gender, etc.) now rival the nation as a basis for collective identity. Politically, much governance now happens beyond states. In short, the modern formation of democracy through the country-nation-state is at best insufficient and at worst obsolete (Scholte 2014, 2019).

Not surprisingly, given this mismatch between old assumptions and new circumstances, many people feel disempowered in today's more global world. As noted already, some antiglobalists have sought to recover democracy by reinforcing territorial borders, reaffirming national identities, and reasserting state sovereignty. However, the supraterritorial, supranational, and suprastate logics of deepened globalisation mean that this approach can achieve only limited democratic gains. One must also democratise spaces beyond the country, peoples beyond the nation, and governors beyond the state. Thus, if one believes that democracy is a cornerstone of living well-and that alternatives such as autocracy and technocracy are unacceptable - then it is necessary 
to look for new formulas of democracy. And indeed a number of theorists and activists have already begun to do so.

\section{Global Democracy: Responses to Date}

This article is hardly the first writing to contemplate the problem of global democracy. An extensive academic literature has accumulated since the 1990s on what has been variously called 'global', 'planetary', 'world', 'cosmopolitan' and 'transnational' democracy (Archibugi et al. 2012; Bray and Slaughter 2015). The ideas in this literature can be classed into six broad categories: i.e. communitarianism, multilateralism, world federalism, global stakeholder democracy, global deliberation, and counter-hegemonic resistance (Scholte 2019). Yet, for all the rich diversity provided across these perspectives, most global democracy thinking to date has remained captive of a liberal imaginary and does not contemplate possibilities beyond a liberal world order.

To underline a key disclaimer, the point of this discussion is not, in radical postmodernist fashion, to dismiss all potential contributions of liberalism to global democracy. Representative assemblies, rule of law, open markets, human rights, and civil society may provide significant voice and influence for many people in many situations of contemporary global politics. However, the critical exploration in this article does insist to ask whether-given persistent limitations of and discontents with liberal world order-liberal democracy is sufficient to realise global democracy. If not, then wider enquiries are required.

The first approach to global democracy thinking, communitarianism, is reflected in the antiglobalist reactions described earlier. Communitarian arguments hold that collective self-determination beyond country-state-nation units is impossible (Miller 1995; Dahl 1999; De Wilde 2011). This sceptical approach holds that: (a) planetary spaces are too large for popular control; (b) no globalscale demos is possible; and (c) global governance institutions cannot adequately connect with constituents on the ground. From a communitarian perspective, globalisation inherently contradicts people's power, and the way to reaffirm democracy in contemporary society is to roll back transplanetary social connectivity and to reinvigorate bordered sovereign nation states. Implicitly, most communitarian thinking presumes that democracy can only take a liberal shape (i.e. of representative government, human rights, civil society, and rule of law) and that such liberal democracy is only available within the confines of a country-nation-state. To this extent, communitarianism is not a post-liberal vision.

Multilateralist conceptions of global democracy suggest that people's power in transplanetary affairs can be achieved through collaboration among democratic nation states (Moravcsik 2004; Keohane et al. 2009). On this formula, the way to democracy in global politics is to universalise liberal democracy across all countries in the world. With liberal institutions secured domestically, a state can serve as the democratic force of its people in intergovernmental organisations (IGOs) where global public policy is made. Those IGOs are themselves democratic when they provide for due participation by and accountability to the democratic member 
country-nation-states. Yet, in common with communitarian visions, multilateralist notions presume that democracy derives in the first place from the modern liberal territorial nation state. So conventional multilateralism, too, offers no post-liberal framework.

A third approach, world federalism, suggests that global democracy can be constructed by introducing liberal democratic institutions directly at a planetary level. In this perspective, global democracy would be realised with the enactment of globalscale representative government, global-scale human rights, global-scale citizenship, and global-scale civil society (Tännsjö 2008; Cabrera 2010). Hence, world federalists embrace proposals for global parliamentary assemblies, initiatives to build global political parties, the development of United Nations human rights machinery, and NGO (nongovernmental organisation) engagement of global governance agencies (Strauss 2005; Patomäki 2011). Yet, while world federalism takes a creative leap by relocating liberal democracy firmly beyond the country-nation-state, this approach holds back from a still more transformative move of transcending liberal democracy itself.

Another and mostly recent innovation, global stakeholder democracy, also scales liberal principles up from country to planetary level. However, rather than the worldfederalist formula of global parliamentary politics, stakeholderism suggests a different way to achieve democratic representation in global governance (Hallström and Boström 2010; Raymond and DeNardis 2015; Gleckman 2018). In so-called multistakeholder initiatives, decision-taking bodies in global governance include positions not only for governments, but also for other sectors such as business and NGOs that may 'hold a stake' in the issue area concerned. Examples of multistakeholder bodies include the International Labour Organisation (ILO), the Forest Stewardship Council (FSC), and the Internet Corporation for Assigned Names and Numbers (ICANN). Yet, novel as these institutional constructions may be, their underlying conception remains wedded to liberal ideas of representative decision-taking, human rights, market economy, and an active civil society. Global stakeholder democracy is post-national, but not post-liberal.

Still further rethinking of democracy for a more global world has focused on deliberation (Dryzek 2006; Smith and Brassett 2008; Stevenson and Dryzek 2014). These ideas about public discussion are less a deviation from, and more a supplement to, the previous three approaches. Deliberative democracy suggests that people's power runs deeper when policy decisions are informed by open, inclusive, rational debate among implicated citizens. Global deliberative democracy takes this principle beyond national to planetary politics, as practised for example in the World Social Forum or in civil society gatherings alongside IGO conferences. Once again, however, this innovative theorising builds upon liberal premises and stops short of questioning them. The deliberative arenas complement representative processes, embrace human rights, celebrate the role of civil society, and endorse the rule of law.

Finally, in this sixfold typology of the main existing perspectives on global democracy, ideas of counter-hegemonic resistance suggest that people's power in global politics is achieved when social movements pursue emancipatory struggles to subvert domination and subordination (Amoore 2005; Smith et al. 2007). Resistance 
conceptions of global democracy have taken heart from mobilisations such as boycotts of global corporations since the 1970s, the Battle of Seattle in 1999, Occupy sit-ins during 2011-12, and (on some interpretations) Brexit in 2016. Yet often such movements have attacked failures of liberal democracy in practice rather than liberal democracy itself: i.e. these critics want better representative democracy, more human rights compliance, and greater civil society influence in global governance. Even on those occasions where resistance thinking on global democracy has taken aim at the normative order of liberalism, the prospective alternatives are generally underdeveloped. For example, what exactly would be entailed in concrete practice and institutional design by 'cognitive justice' (De Sousa Santos 2007), a revived Ummah (El-Ghazali 2001), and 'earth democracy' (Shiva 2005)?

Thus, 20 years of global democracy research have produced a breadth and depth of ideas concerning people's power in transplanetary politics. The sixfold categorisation presented here is obviously a simplification, and many individual works on global democracy straddle and combine several of the approaches. Still, this review has sufficed to demonstrate that, for all the diversity and innovation, academic research to date has on the whole held back from deeper rethinking of democracy beyond liberalism. What could account for these limits to creativity? In particular, are there aspects of research methodology which have restricted the range of knowledge produced?

\section{Methodology Matters}

If definitions are substantially a product of their context, then it matters who defines and how. Regarding 'who', participation in (and exclusion from) an exercise of knowledge construction affects the resulting conceptions. Regarding 'how', the process of definition - the way that concept building is undertaken-shapes the resulting ideas.

So it is with notions of global democracy. Who determines what this concept means more precisely, and how do they produce this knowledge? Different researchers using different research processes could generate quite different understandings of global democracy. Methodology matters.

Hence, we should ask: under what conditions have currently available conceptions of global democracy emerged? In particular, are there circumstances of knowledge production that have predisposed the resultant ideas to take predominantly liberal (and not other) forms? Could deliberate deviation from those methodological conditions encourage the creation of new and different post-liberal insights?

Looking at authorship on global democracy to date, it has had strikingly narrow geopolitical, cultural, disciplinary, sectoral, and social bases. Geographically, most of the work has emanated from sites in North America and Western Europe, with little or no input from other world regions. Culturally, existing formulations of global democracy have developed almost exclusively within western modern frames, with little or no awareness of-let alone involvement from-other life-worlds. Intellectually, academic reflections on global democracy have come mainly from the field of 
political theory, with few contributions from other disciplines. Sectorally, research on global democracy has primarily unfolded in introspective academic quarters, with scant engagement of practitioners in business, civil society, media, official, and technical circles. Socially, most published arguments concerning global democracy have come from able-bodied middle-aged urban-metropolitan professional straight white men.

In short, knowledge production about global democracy has thus far mostly transpired in quite restricted quarters. Moreover, those circles for the most part involve sites of privilege and power: dominant regions, dominant cultures, dominant social groups. Is it coincidence that liberal conceptions of global democracy have emerged under these conditions? Can we then be so confident, as liberal theorists tend to be, that these ideas speak to a universal 'human nature'? On the contrary, could there not be prima facie grounds to enquire whether liberal ideas of global democracy are artefacts of hegemony?

In this case, we can wonder whether liberal constructions of global democracy resonate-i.e. would be experienced as veritably democratic - for all, or even most, of the world's population (cf. Held and Patomäki 2006). Indeed, it is notable that concrete struggles for people's power in global politics rarely invoke liberal academic literature. On the contrary, grass-roots campaigners often receive ideas of multilateralism, world federalism, global stakeholderism, and deliberative democracy with scepticism. Such at least has been the present author's experience from hundreds of interviews with democracy activists across the planet (Scholte 2004).

So the invitation is to try something different: to devise alternative ways of generating ideas about global democracy. Perhaps reconstructed knowledge production processes still yield a largely liberal framework - and thereby corroborate that perspective's claims to universalism. However, contrasting methodologies might instead generate something different-and perhaps also more compelling for today's global world. Given that the stakes involve no less than the future of democracy, it seems important at least to probe an alternative way.

On this inspiration, one might challenge mainstream conditions of knowledge production about global democracy with three principles of diversity, reflexivity, and praxis. Diversity means moving from narrow to broad authorship. Reflexivity entails moving from negligence to vigilance about positionality. Praxis involves moving from insular academe to engaged politics. Maybe such features-strikingly absent in established ways of theorising global democracy-would generate different ideas?

To elaborate on the principle of diversity, global democracy scholarship to date has, as seen earlier, strikingly omitted more voices than it has included. In contrast, an alternative methodology could pursue greater comprehensive coverage, where equivalent access to conversations about global democracy is sought for all world regions, all life-ways, all academic disciplines, all vocations, and all social groups. So, for example, one would seek to have more say from the global south, from religious epistemologies, from humanities, from activists, from women. To be sure, a completely inclusive and non-hierarchical discussion is unachievable; however, global democracy debates can certainly have much wider participation than has been witnessed so far around liberal theory. 
Regarding reflexivity, the global democracy studies reviewed earlier rarely involve an explicit awareness of, and critical stance towards, positionality. In other words, the theorists and activists in question do not explicitly identify their specific context - where they are coming from - and foreground its implications for the way that they understand the world. Rather, and reflecting the universalistic assumptions of modern liberalism, mainstream authors on global democracy generally presume that they express truths that transcend history and culture. In contrast, reflexivity demands that researchers undertake probing critical contemplation of their selves and their relationships to society and its power structures (Giddens 1984; Bourdieu and Wacquant 1992). The resulting heightened awareness of positionality gives reflexive knowers greater capacities to act deliberately and transformatively in respect of their selves and their social order. Such sensitivities could enhance possibilities to develop novel post-liberal notions of global democracy.

Regarding praxis, existing liberal knowledge of global democracy, as catalogued earlier, has generally been formulated within closed academic quarters, where professional researchers have mainly engaged with, and written for, other professional researchers. This insularity may leave scholars insufficiently informed about the concrete conditions of global politics that their research means to address. Normative theorists in ivory towers can be quite divorced from actual governance processes and political struggles. In contrast, praxis puts academics in intense interaction with nonacademics, as found in civil society associations, commercial organisations, expert groups, grassroots movements, media networks, official circles, and political parties. Academic ideas of global democracy may then more directly speak to people's actually experienced desires and needs. Scholars may also become more alert to the possible practical use (and misuse) of the knowledge that they formulate. Praxis might thereby allow researchers more effectively to advance the global democracy that they claim to want (cf. Scholte 1993; Scheper-Hughes 1995). As expressed by Sue Sohng, 'The result of this kind of activity is living knowledge that may get translated into action' (1997: 62).

In sum, a search for new notions of global democracy can do well to start with new methods. Principles of diversity, reflexivity, and praxis would put global democracy research on a radically different footing than seen in other studies to date. How might such an approach be implemented in practice? And would the exercise yield inventive post-liberal insights on people's power in a global world?

\section{Building Global Democracy: An Experiment in Alternative Methodology}

Taking inspiration from the concerns and suggestions discussed above, the BGD programme (2008-2014) experimented with different ways of developing ideas about global democracy. Over six years, the programme convened five projects to explore new thinking about people's power in global politics. The projects respectively examined conceptual, pedagogic, institutional, economic, and cultural aspects of global democracy. Each project involved a different group of individuals, 
numbering 160 in all. Coordination across the five projects was provided by a convening group of ten persons.

Concrete results of the BGD experiment are published elsewhere (e.g. Scholte 2015; Scholte et al. 2016; Scholte forthcoming). The concern of the present article is less with specific outputs and more with the BGD research process and its consequences. The following paragraphs indicate how BGD implemented principles of diversity, reflexivity and praxis, while the sixth section of the article considers how this alternative approach affected the resulting knowledge of global democracy.

\subsection{Diversity}

With a guiding principle of diversity, BGD aspired to open a space where any and all parties could have access and feel safe to speak (or not to speak, if such were their disposition) about their ideas concerning people's power in global politics. Diversity among the 160 BGD project participants had multiple dimensions. Academically, participation in the programme ranged across the social sciences and humanities. Geographically, BGD projects always combined participants from ten world regions in equal proportions, including from often overlooked places such as small island states. Culturally, BGD brought together people with diverse lifeworlds, life-ways and life-styles - that is, persons who inhabited different mindsets as well as different territorial locations. Linguistically, the programme issued its main materials in Arabic, Chinese, English, French, Hindi, Portuguese, Russian, and Spanish. Socially, BGD maintained gender balances in all activities and consistently ranged across generations and races, with openings also across castes, classes, differing abilities, and sexual orientations. Sectorally, participation in BGD activities fell on a roughly 50/50 distribution between academics and lay circles (in business, civil society, media, governance bodies, and political parties). Ideologically, BGD discussion groups encompassed wide varieties of both religious and secular political outlooks. In these ways, BGD went far beyond liberal research on global democracy in terms of putting different positionalities in conversation with each other.

These multifaceted diversities were incorporated into all aspects of the BGD programme. For example, the ten conveners heralded from eight academic fields, ten world regions, and eight mother tongues. Their cultural and ideological frames included Confucian thought, Gandhian praxis, indigenous knowledge, liberalism, Islam, postcolonialism, and Russian modernism. Likewise, each of the five BGD workshops had, as one participant remarked, a 'rainbow' quality, with 'different cultures, colours and standards of life' (Rio 2011). Diversity was also proactively pursued in the construction of the BGD database, which eventually spanned 6600 persons in 162 countries across a broad range of social groups and sectors.

In contrast to mainstream political theory workshops, which usually meet in the Global North, BGD discussions convened at globally spread locations in Cairo, Delhi, Rio de Janeiro, Pretoria/Tshwane, and Duisburg. Each event included interactions with local groups alongside the workshop sessions. Further to encourage dialogues of diversities, discussants of papers were always assigned writings from a different regional, cultural, sectoral, social and/or ideological position than their 
own. Workshops moreover operated with flexibility regarding performance rituals, time management, spatial layout, and even ambient temperature in order to address the various participants' differing expectations.

Outputs from the various BGD discussions were also designed and disseminated with a view to promote accessibility for diverse audiences. In addition to academic writings, BGD projects generated press interviews, social media discussions, videos, and activist toolkits. Moreover, the main BGD website pages, project briefings, and workshop paper summaries were translated into the eight aforementioned languages. BGD conveners engaged with three World Social Forums, numerous civil society organisations, various national governments and intergovernmental agencies, slum communities in Rio de Janeiro, and grassroots mobilisations for global democracy such as Give Your Vote and Occupy.

With this comprehensive priority for diversity, BGD sought to break out of the narrow mould that has marked liberal global democracy research. No other conversation about people's power in global politics has so deliberately, systematically and deeply involved more regions, more cultures, more disciplines, more sectors, more social positions, and more political persuasions. As elaborated later, this cultivation of diversity did indeed yield alternative knowledge of global democracy.

\subsection{Reflexivity}

Along with diversity, a second distinctive methodological cornerstone for BGD's pursuit of more open and searching constructions of global democracy was reflexivity. This stance was encouraged in order that programme participants would be acutely conscious of their own positions vis-à-vis the various diversities that assembled in the projects. Attendees were urged constantly to ask, 'How does my positionality affect my thinking about global democracy?' Contributors continually made their assumptions about globality and democracy explicit to themselves and to other contributors. Even the very terms 'global' and 'democracy' were subjected to vigorous critical interrogation across the different workshops. Thus, BGD activities were intended to be moments of intense introspective examination that could open the way to new thinking on global democracy.

Also in the spirit of reflexivity, high priority was placed in BGD discussions on communicating differences. The workshop ethos stressed recognition of, respect for, listening to, learning from, and being changed by divergent perspectives on people's power in global affairs. 'Deep listening' in the BGD setting involved concentrated, careful and patient attention that strives maximally to hear, empathise with, receive from, and respond to the views and experiences of others. Thus, BGD not only brought, say, Islamists and LGBT+ activists into the same room, but also invited people with apparently incommensurable positions seriously to exchange with each other.

An emphasis on reflexivity furthermore led BGD proceedings to give particular attention to connections between knowledge and power. The programme recognised that the diversity of views which contributors expressed in workshops partly reflected their various-and sometimes clashing-political interests. A person's 
perspective on global democracy often reflects the material, ideological, and status advantages that they might obtain from that approach. Underlining these knowledge/ power links, BGD encouraged participants to construct visions of global democracy that best served their own political struggles, even if this orientation drew their thinking away from the dominant liberal paradigm.

Acute concerns about the implications of context and power led BGD conveners to give continual and quite exhaustive attention to process. Everything including the programme's core questions and main project themes was regularly revisited and, on multiple occasions, revised. Full details about the formulation, implementation and review of the programme were made public, inter alia through the BGD website and a quarterly newsletter, in order to invite scrutiny and challenge from observers. In response to such critical feedback, several project frameworks and titles were altered, a number of workshop practices were adjusted, various funds were reallocated, and several new types of outputs were devised.

A premium on reflexivity generally made BGD proceedings more time-consuming and cumbersome than other academic work on global democracy. Outputs flow faster when there is less examination of underlying principles. Still, BGD considered that deep reflexivity could cultivate knowledge of global democracy that is more open to new possibilities and more attuned to the actual circumstances of people's lives. This is not to suggest that other (mainly liberal) global democracy research has been wholly unreflexive; however, that work has not examined with similar insistence the ways that context and power shape knowledge.

\subsection{Praxis}

As a third methodological contrast to most pre-existent global democracy research, BGD invoked praxis. Thus, the emphasis was not on eloquent articulation for academic performance, but on grounded knowledge for political impact. Although BGD took important input from scholarly literature, the programme relied more on what others have called 'practice-research engagement' (Brown 2001), 'action research' (Reason and Bradbury 2008), and 'pracademics' (Posner 2009).

As already mentioned, participation in BGD projects was evenly split between professional scholars and non-academic practitioners. At every corner, the programme underlined cross-sectoral dialogue: in the articulation of research questions; in the development of research design; in the collection and interpretation of evidence; in the preparation of outputs; in the distribution and application of findings; and in ex post evaluations of the project. The ethos was joint enquiry and mutual creativity across academic-lay lines.

More specifically, the BGD convening group consisted of action-oriented researchers who had alongside and within their scholarship also worked as civil society activists, legislators, media commentators, and policy consultants. Similarly, contributing researchers in the five BGD projects generally had close ties with global politics outside academe. Several BGD papers were co-authored between a researcher and a practitioner (Ata and Halapua 2011; Bradlow and Molokoane 
2011). Lay respondents in BGD workshops analysed the political implications of global democracy proposals to a more practically informed extent than professional academics would normally be inclined or able to do. As noted earlier, BGD geared its outputs to practitioner as well as academic circles, with videos, toolkits, and so on. The links section of the BGD website included several hundred non-university organisations. In addition, half of the programme database (over 3000 of the entries) were non-academic correspondents.

In enacting praxis, BGD gave particular attention to involving participants from subaltern positions in global politics. Thus, in stark contrast to other global democracy research, the programme incorporated direct contributions from Dalits, indigenous groups, people of colour, persons living with disability, LGBT+circles, small countries, underclasses, unrecognised nations, various religions, women, and youth. In this way, BGD strove in its own methodology to counter prevailing power hierarchies that impede global democracy.

In sum, the BGD experiment showed that, with deliberate effort, it is possible to conduct research on global democracy in different ways than have generally prevailed to date. With diversity, the research process can take inputs from and gear its outputs to a broad spectrum of regions, cultures, disciplines, sectors, and other social categories. With reflexivity, knowledge of global democracy can be produced with acute awareness of these diversities and associated power relations. With praxis, ideas of global democracy can be formulated with intense concern for the practical implications of those conceptions. By combining diversity, reflexivity, and praxis, the methodology of global democracy research can itself become more democratic, with more visibility, more accessibility, more consultation, and more accountability vis-à-vis affected global publics.

\section{Alternative Knowledge}

Then comes the crunch question: has the method mattered for outcomes? Does the pursuit of global democracy research on methodological principles of diversity, reflexivity, and praxis generate different kinds of (post-liberal) ideas? If so, could this alternative knowledge also promote deeper actual democracy in current and future global affairs? In particular, do the post-liberal propositions offer more entry, voice, and influence in global arenas to people who have found limited empowerment in the liberal world order?

As elaborated in the following paragraphs, the BGD dialogues generated five notable shifts from mainstream knowledge of (liberal) global democracy. These novelties involved: (a) daring to transform democratic practice; (b) reimagining the demos in global politics; (c) reconstructing channels of democratic action; (d) rethinking interconnections between global democracy and global justice; and (e) confronting structural power hierarchies in global politics. 


\subsection{Daring to Transform}

To elaborate on the first of these five consequences, a methodology focused on diversity, reflexivity, and praxis in the BGD programme encouraged far-reaching innovation around global democracy. Liberal theorising - with its generally narrow base, complacency, and insularity - has by comparison refrained from major creative leaps. In contrast, BGD conversations only partly — and often only marginally — spoke of global democracy in terms of political parties, plebiscites, and parliaments. With the different methodology, people's power in global affairs became not a question of moving liberal principles from the national to the planetary scale, but a matter of reinventing democracy itself.

In this innovative vein, BGD discussions related global democracy to a panoply of issues which have not figured prominently, if at all, in liberal political theory. These alternative angles included linking global democracy to culture (Yang 2014), diaspora (Mullings and Trotz 2016), ecology (Lander 2010), gender (Mohammed 2010), indigeneity (Stewart-Harawira 2011), race (Campbell Barr 2011), sexuality (Vance 2011), and spirituality (Mostafa 2010; Singh 2010; Ghani 2011). In terms of democratic practices, too, BGD deliberations envisioned public involvement and control in global affairs through non-electoral venues as varied as new social media (Vartanova 2011), satellite television (Ayish 2011), social forums (Della Porta and Doerr 2011), storytelling (Halapua and Halapua 2010), street performances (Ford-Smith 2011), truth and reconciliation processes (Ata and Halapua 2011), and alternative education Oommen 2011; Sichone 2011; Vainer and Vieira 2011; Zhu 2011). Thus, diversity, reflexivity, and praxis substantially expanded the political imagination regarding global democracy.

In addition, BGD's alternative methodology promoted innovation by abandoning the liberal premise of a singular universal concept of global democracy. BGD discussions continually underlined that people's power in global politics is heterogeneous, contextual, and fluid. Given enormous diversities across space, as well as rapid transformations across time, building global democracy in contemporary society cannot be an exercise in consensus formation around one definitive conception for all humanity. The BGD experience strongly suggested that convergence on the same principles and practices of global democracy is not in prospect between, for example, a youth assembly in Armenia, a peace initiative in South Asia, an indigenous movement on Turtle Island, an Islamic striving for the Ummah, and a black women's collective in Latin America. Imposing a uniform transplanetary blueprint is not viable.

It would therefore seem misguided to seek 'the answer' to 'the problem' of global democracy, through whatever liberal or other formula. Instead, diversity suggests that theory and practice should embrace pluralism and foster many concurrent paths towards people's power in global politics. Reflexivity suggests that researchers and practitioners should listen to context-inevitably variable-and nurture visions of global democracy - inevitably multiple - that speak to divergent situations. Praxis suggests that global democracy scholars and activists should develop different propositions to suit differentially placed constituencies: what empowers one site may disempower another. In short, post-liberal global democracy would involve creative living through 
differences: a coexistence of numerous, continually evolving, and sometimes clashing exercises of people's power.

\subsection{Reimagining the Demos}

A more particular point of innovation that emerged through the BGD experiment concerns the contours of 'the people' in global democracy. How do political community and social solidarity operate in planetary realms? What does 'the public' look like in global affairs? The BGD application of a diversity-reflexivity-praxis methodology led to more complex constructions of the demos in global politics, in contrast to the narrower liberal focus on nations and international community.

Liberal world-order thinking arguably holds unduly limited notions of the demos for contemporary globalised society. Communitarian and multilateralist variants of the liberal paradigm assume that the nation is the only-or in any case the overriding - construction of 'the people'. However, today as throughout history, many purported national communities are in fact fragile and contested. Moreover, mobilisations in global politics often activate other bases of collective solidarity besides the nation, such as class, faith, or indigeneity. For its part, liberal world federalism suggests that 'the people' in global democracy takes form as a universal community of humankind. However, this conception tends to sideline more particularistic solidarities (e.g. around gender, language, and race) that also drive much political action on global issues. Meanwhile, stakeholder perspectives on global democracy concentrate on interest groups that are primarily driven by instrumental rationality. Stakeholder theory has little to say about ideological and affective bonds that can also make a 'people' in global politics. Notions of global deliberation underline that political discussions should involve voices from all affected circles, but the approach offers less guidance on how the various constituencies could collectively form a global-scale demos. Resistance perspectives provocatively suggest that talk about a purported 'international community' as often as not disguises arbitrary inequalities and structural injustices. Some of these counter-hegemonic deconstructions also suggest that various nonterritorial solidarities (e.g. of aboriginals or workers) can drive progressive global politics. However, resistance thinking has offered less guidance regarding the concept of a global demos.

By emphasising diversity, BGD research developed a pluralist understanding of 'the people' in global politics. Programme participants embraced multiple and varying touchstones of political solidarity in planetary politics, including age, caste, class, disability, faith, gender, humanity, indigeneity, nationhood, race, and sexual orientation (Mostafa 2010; Mwatha 2010; Williams 2010; Bu 2011; Kumar 2011; McKeon 2011; Nizamova 2011; Stewart-Harawira 2011; Vance 2011). Some BGD contributors also located solidarity in global affairs at a crossroads of several identities: for example, with combinations of gender and race, or of age and class (Campbell Barr 2011; Ford-Smith 2011). Thus, the BGD discussions tended to reinforce the proposition that global democracy should be framed not in terms of a single demos, but rather plural demoi (Bohman 2007). Inasmuch as one might speak of 
'the people' in global democracy, this demos would exhibit a multifaceted and diffuse character (McCall 2005; Yuval-Davis 2011).

The key point here is that plural bonds need not contradict global solidarity. It does not necessarily follow, as communitarians would have it, that cultural differences make a global demos impossible. Nor must it be, as world federalists would have it, that a global demos requires a single universal cultural footing (in western liberal modernity). Instead, a methodology focused on diversity, reflexivity, and praxis suggests that democratic global cooperation can actually be positively grounded in cultural differences. The final BGD project, on 'Global Democracy through Cultural Diversity', explored how such dynamics could operate (Scholte 2015).

This proposal for an alternative 'transcultural' global solidarity has its bedrock in reflexivity. The BGD experience showed that a demos-through-diversity is possible in global affairs if all parties are constantly alert to, and questioning of, the particularity and contextually bound character of their own ideas and practices of people's power. With transculturalism, no position-liberal or otherwise-makes universalist claims. Moreover, global democracy-through-difference is enhanced when the parties openly recognise the power relations (and inequalities) that mark their encounters-and deliberately work to minimise the effects of arbitrary dominations (by age, class, gender, language, etc.). BGD workshops also demonstrated in microcosm that global solidarity can be furthered when, instead of imposing oversimplifications, parties accept that identities and solidarities in global politics are irreducibly complex. Likewise, people can welcome diversity as a resource and opportunity for global cooperation, instead of lamenting it as an inevitable driver of fragmentation, opposition, and violence.

Such a reimagined demos-as-demoi is vital for people's power in a post-liberal world order. Centuries of imperialism have shown that liberal insistence on a monochrome international community breeds resentment and revolt. Liberals have waited many generations for the rest of humanity to become like them, but the convergence persistently fails to happen. Nor will any other universalistic claim prevail, whether from a religious faith, indigenous wisdom, or whatever. Instead, global solidarity may arise when liberal framings of national and international demos engage transculturally with other constructions of 'the people'. But the conversation must transpire on a level playing field: with full mutual respect, listening, learning, and change-also and in particular on the part of liberals. In this way, deep and empathetic negotiation of differences can provide an affective glue for post-liberal global democracy.

\subsection{Reconstructing Channels}

A methodology centred on diversity, reflexivity, and praxis - as pursued through the BGD programme - also generated alternative ideas about institutional designs for global democracy. What organisational forms and procedures can make people's power effective in global politics? Through what channels does one concretely execute global democracy? 
Liberal institutional designs for achieving global democracy have not fully convinced. As seen earlier, multilateralist conceptions of global democracy have focused on intergovernmental organisations. Yet state delegates and NGO activists at the headquarters of an IGO are so very far removed from the everyday lives of most of the affected people whom they claim to represent. World federalists have promoted an elected planetary government as the institutional formula for global democracy. However, planetary plebiscites are a remote prospect and-were they somehow to become practicable - would hardly give billions of constituents across the planet much veritable involvement in global policy processes. More recent liberal global democracy thinking has promoted multistakeholder designs as well as deliberative forums. Yet global multistakeholder processes have so far operated mainly through small insider clubs that have limited engagement with, or accountability to, wider publics. For their part, global deliberative arrangements have exerted little direct impact on actual policy decision and implementation. Finally, resistance strategies of global democracy seek to subvert existing institutional apparatuses of global governance, but generally without working out an alternative institutional vision. Lacking enough proposal alongside the protest, counter-hegemonic mobilisations have tended to be sporadic, small scale, short term, and relatively ineffectual.

In the BGD programme, a methodology built around diversity, reflexivity, and praxis brought these shortcomings of liberal institutional designs into sharper focus. In fact, most contributors to the five projects did not link planetary democracy to IGOs, world government, global multistakeholder bodies, or global deliberative forums. Apparently, then, the world's people when taken in their manifold diversity (as BGD attempted to do) usually do not associate people's power with the organisational sites where liberal global democracy proposes to locate it. Likewise, when building on praxis, BGD explorations suggested that liberal visions of global democratic institutions resonate little beyond academic political thought. Perhaps more reflexive liberal theorists would also concede that their prescriptions, when put into concrete practice through IGOs and multistakeholder arenas, foster little in the way of actual broad popular participation and control.

But if liberal institutional designs are insufficient, certainly by themselves, then what other organisational channels could increase global democracy? Not surprisingly, given its methodological emphasis on diversity, the BGD programme did not come up with an alternative single formula. Rather, the suggestion was that different constituencies would develop different modes of global democratic expression. For example, talanoa practices from the Pacific and hehe ideas from China could reframe global negotiation in more democratic fashions (Halapua and Halapua 2010; Xu et al. 2010). Practices of jihad could provide collective self-realisation for Muslims and (with adaptations) others in global affairs (Mostafa 2010). Frameworks of 'buen vivir' and 'florestania' could bring indigenous democratic practices from Latin America into global-scale governance (Maldonado 2009; Gudynas 2011). Priorities on egalitarianism and living together, especially prevalent in BGD contributions from Africa, could imply very different institutional set-ups for global governance than the currently prevailing more hierarchical and competitive arrangements (Musamba 2015). To be sure, liberal propositions can stay in the mix of institutional 
designs for global democracy, but in a post-liberal order they become one set of possible answers, among many, rather than the a priori dominant reference point.

Indeed, an emphasis on reflexivity allows channels of people's power in global politics to evolve through transcultural learning over time. Participants in BGD projects generally left the conversations as changed persons with new perspectives and new ideas for action. Thus, altogether new channels for global democracy could emerge in the decades ahead as reflexive agents critically consider the promises and the limitations of different institutional designs-liberal and other-and then creatively recombine elements from various constructions in order to meet novel situations of a more global world.

\subsection{Rethinking Global Justice}

An exploration of global democracy that emphasises diversity, reflexivity, and praxis also tends - at least in the case of the BGD experiment-to generate postliberal conceptions of the links between democracy and justice in planetary politics. Liberal thought on global democracy has mainly approached global justice in terms of human rights (especially of civil and political kinds), open elections, free markets, and the rule of law. In contrast, BGD discussions-by bringing in a rainbow of perspectives, by reflecting critically on power relations, and by engaging closely with actual political struggles-took debates on global equity much wider, in particular to include distributive justice, cognitive justice, gender and racial justice, and ecological justice.

Regarding distributive justice, liberal thought on global democracy has generally not systematically addressed - and indeed has often remained silent onquestions of fairly sharing material resources across humanity. Yet how can one begin to discuss meaningful people's power in planetary politics when the global Gini coefficient stands as high as 70 (Milanovic 2009) and when $0.7 \%$ of the world population controls $45.9 \%$ of capital assets (Crédit Suisse 2017)? Liberal proposals for multilateralism, world government, multistakeholder governance, and global deliberation do not foreground aims for more equitable distributions of resources. Indeed, liberal silence on matters of redistribution in effect serves to perpetuate the gross economic inequalities that mark contemporary world society.

In contrast, a methodology of diversity, reflexivity, and praxis irrevocably welds global democracy to global distributive justice. By involving all world regions and social sectors, BGD proceedings could not but spotlight links between democratic deficits in global politics and maldistribution in global economics (Scholte et al. 2016). Many BGD contributors-particularly from the global south and from social movements-insisted that building global democracy must have substantial global redistribution at its core (Xu et al. 2010; Bradlow and Molokoane 2011; McKeon 2011; Adamovsky 2012; Bedirhanoğlu 2016; Fedotova 2016; Geist 2012; Hall and Kaul 2016; Kwa 2012; Liu and Huang 2016; Tandon 2016; Weber 2016). Moreover, reflexivity pushed BGD projects to make connections between economically privileged authors and universities on the one hand and (liberal) knowledge that did not identify or question material 
inequalities on the other. Praxis meant that BGD workshops involved many participants who directly faced the harms of global maldistribution in their daily lives and therefore insisted that these issues be addressed at the heart of a planetary democracy programme.

Shifting from material to ideational issues, alternative methodology also drew BGD to questions of cognitive justice: that is, a situation where all life-worlds in principle enjoy recognition, respect, voice, and autonomy (De Sousa Santos 2007). Liberal thinking on global democracy has shown little cultural reflexivity, rather blithely assuming that people's power on a planetary scale would and should rest on western modern foundations. None of the six conceptions reviewed earlier offers guidance on how to incorporate cultural difference into global democracy, so that the practices would be experienced as actual people's power across the divergent life-worlds that inhabit global publics. In contrast, as discussed earlier, positive transcultural ethics figured at the heart of the BGD process and outcomes.

Methodological emphasis on diversity, reflexivity, and praxis further encouraged a BGD concern with gender and racial justice that has been lacking in liberal research on global democracy (cf. Anievas 2015; Eschle 2001). Gender diversity among BGD participants promoted frequent explicit discussion of the structural subordination of women worldwide and the indispensability of gender equity for any meaningful global democracy (Mohammed 2010; Mwatha 2010; Vance 2011). Similarly, diversity and reflexivity on matters of race across the BGD programme made visible injustices related to colour that have been comprehensively ignored in liberal theorising on global democracy (Campbell Barr 2011; Stewart-Harawira 2011; Mullings and Trotz 2016).

Looking for different approaches (with diversity), questioning common sense (with reflexivity), and engaging concrete agendas (with praxis) also drew BGD to ideas of ecological justice that are not found in conventional anthropocentric thinking on global democracy. True, certain research has considered how global environmental governance could be democratised (Bäckstrand 2006; Stevenson and Dryzek 2014); however, it is a qualitatively different matter to place ecological care at the heart of democratic principles and practices (Shiva 2005). Thus, a number of contributions to BGD urged that global democracy must at its core operate in harmony with, and nurture, the overall web of life (Lander 2010; Cordeiro Ferreira and de Oliveira Filho 2011; Stewart-Harawira 2011; Guerrero 2016).

In sum, post-liberal global democracy would, on the methodology practised through the BGD programme, involve wider and heightened attention to issues of justice. It is not that such a world order would necessarily wholly reject liberal principles of human rights, representative government, and rule of law; however, postliberal global democracy would have considerably more demanding requisites for global justice.

\subsection{Confronting Power Hierarchies}

Closely related to deeper concerns with global justice, alternative methodology led the BGD programme to link the democratisation of global affairs with challenges 
to arbitrary power hierarchies. Fighting structural discrimination is today widely emphasised in respect of national democracy. Thus, reigning consensus across much of the world says that, for a country to be veritably democratic, national politics must vigorously confront entrenched subordinations on lines of (dis)ability, gender, faith, language, race, region, sexual orientation, and so on. Yet, paradoxically, liberal thinking on global democracy has generally said little against embedded power hierarchies in contemporary world order. Dominations which are treated as unacceptable on a national scale are tolerated on a global scale. In contrast, methodological emphasis on diversity, reflexivity, and praxis brought subversion of arbitrary structural power to the core of global democratisation in the BGD programme.

Indeed, diversity reduced global power structures within the five BGD projects themselves. Thus, for example, regional diversity in BGD participation ran counter to north-south hierarchies. Diversities in BGD workshops around age, caste, class, (dis)ability, gender, race, and sexuality ran counter to social hierarchies. Faith and linguistic diversities in the programme ran counter to the structural power of modern rationalism and English. As a result, many voices that are normally subordinated in world politics took centre stage in the BGD discussions and thereby changed the substance of global democracy debates. Once empowered, these voices refused to be silent.

A focus on diversity also led BGD investigations to consider multiple power hierarchies simultaneously. Much critical thinking on global politics has highlighted a single axis of structural discrimination: e.g. core-periphery in the case of dependency theory; class in the case of Marxism; gender in the case of feminism; heterosexism in the case of queer theory; and so on. In contrast, BGD proceedings and outcomes confronted multiple dominations and often highlighted their interconnections. By implication, then, a post-liberal democratisation of global politics would need concurrently to subvert a range of geographical, social, and cultural hierarchies.

This is not to claim that the BGD initiative was itself free of structural power. On the contrary, the programme's core funding came from a major US-based corporate foundation. BGD offices were located at a well-resourced university in Britain. The working language of BGD was English. Participants in BGD projects were disproportionately middle-class professionals. Thus, for all that BGD expressed opposition to arbitrary hierarchies in contemporary global politics, the programme itself also reproduced some of those discriminations.

Still, in contrast to liberal complacency, BGD proceedings with their focus on reflexivity were conscious of, and highly uncomfortable with, these power relations. BGD work therefore involved ongoing explicit discussion of arbitrary hierarchies within the programme itself. Arguably, this self-critical examination of structural power helped BGD to reduce (albeit not eliminate) the impacts of inequalities on its own operations and outputs. In particular, reflexivity encouraged structurally privileged participants in BGD conversations to recognise their arbitrary advantages and to acknowledge a democratic obligation to unlearn and discard associated practices of domination. Thus, even if the ambition to overcome structural inequalities was not fully realised in BGD practice, consistent and persistent attention to arbitrary hierarchies helped to expose their workings 
and loosen their hold, certainly as compared with mainstream global democracy research.

In sum, then, the BGD experiment shows that an alternative methodology of global democracy research can produce knowledge that, on at least five major points, departs markedly from liberal conceptions. The overall conclusion is that post-liberal global democracy would do well: (a) to be ambitiously transformative; (b) to empower plural and intersecting collective identities; (c) to develop transcultural approaches to democratic practice; (d) to pursue multifaceted and deeper global justice; and (e) squarely to confront arbitrary global power hierarchies. To be sure, as discussed in the next concluding section, BGD prescriptions for post-liberal global democracy are not without problems, but different methodology has generated a provocative and perhaps more promising agenda for future research and practice.

\section{Conclusion: Challenges Ahead}

This article started from the observation that contemporary globalisation and associated social changes have critically undermined democracy as known in liberal modern thought and practice. It was suggested that the construction of a future post-liberal global democracy could begin with a reconstruction of the research process. The proposed alternative methodology stressed diversity, reflexivity, and praxis. Implementation of these principles in the Building Global Democracy programme (2008-2014) yielded radically new knowledge and practice in five important ways.

That said, the BGD programme has provided only outlines of a different and prospectively deeper people's power in the present and future more global world. The five BGD projects have generated broad guidelines for possible post-liberal global democracies, but further pursuit of this vision faces several large challenges, including elaboration, habit, power, resources, and uncertainty.

Regarding elaboration, each of the principal innovations that resulted from the alternative methodology in BGD work wants more specification. So, for one thing, how can the political energy for daring transformation of people's power in global politics be sustained and productively channelled? How, more specifically, can individuals and society at large constructively negotiate the greater complexity of community and solidarity that results from plural demoi in global politics? How does one select among the many non-liberal democratic practices available across the world - and then transculturally combine them, also with positive qualities of liberalism? What, more precisely, is entailed by post-liberal global justice, with its cognitive, distributive, ecological, gender, and racial dimensions? How, more exactly, can arbitrary power hierarchies in global politics be effectively confronted and overturned? Each of these elaborations involves a large research agenda and political programme in itself-and then the various streams of postliberal global democracy also need to be interwoven in an overall whole.

Regarding the challenge of habit, proponents of post-liberal global democracy must anticipate that deeply entrenched orthodoxies concerning the nature of democracy will stubbornly resist displacement. Liberal conceptions of people's 
power-with their emphasis on representative elected government, civil and political human rights, and the rule of law through the nation state-have dominated modern discourse for several centuries. It takes little effort to repeat takenfor-granted reigning truths, while (as the BGD experience showed) enormous intellectual and political energies are required to build something new. Habit and inertia give clear advantage to the established paradigm of liberal democracy, however inadequate and obsolete it might be for people's power in the contemporary more global world.

Habit also reigns strong in conceptualisations of world politics. Globalisation may in practice have rendered obsolete territorialist premises about geography, nationalist premises about community, and statist premises about governance. Still, these ontological assumptions-built up over several centuries of modern history-retain a stubborn hold on the current consciousness of most policy elites, general publics, and political theorists. Trends in the so-called emerging powers are no exception to this rule: on the contrary, territorialism, nationalism and statism reign strong in Brazil, China, India and Russia. These notions are moreover continually reproduced through most school curricula, mass media, and other public communications. To be sure, mentalities have also shifted over recent history: consider that 'global' discourse was barely spoken before the 1980s. Nevertheless, purported 'instincts' about 'international relations' remain hard to displace in many quarters.

Habit is moreover hard to break when it is backed by considerable power. Liberal constructions of global democracy, as well as 'international relations' thinking in general, draw strong backing from dominant sites in world politics, both state and nonstate. These forces can also be expected to oppose post-liberal innovations-e.g. towards wider and deeper global justice-which would reduce their privileges of established power. Most dominant actors want to keep their dominance, however undemocratic its foundations might be.

A fourth major challenge for further development of post-liberal global democracy thinking relates to resources. The BGD programme was fortunate to obtain US\$1 million from a major endowment, but this financial support was exceptional. Mainstream foundations and academic research councils rarely prioritise methodologies based on diverse participation, critical deconstruction, and action orientation. Funder reluctance generally increases all the more when a 'high-risk' project proposal challenges prevailing knowledge/power. In contrast, relatively greater funding is available to support 'safe' liberal research on established lines of global governance, human rights, market economy, and the like. Still further resource difficulties could be expected when it comes to seeking means to put post-liberal visions of global democracy into practice through counter-hegemonic movements.

Finally, as already intimated with the 'high-risk' designation, further development of post-liberal ideas of global democracy faces challenges of uncertainty. Liberal conceptions of people's power bring the security of familiarity. In contrast, postliberal proposals for transformation, complex identities, non-modern techniques, reconstructed justice, and a subversion of established power hierarchies are suffused with unpredictability. Indeed, certain other historical experiments with alternatives 
to liberal democracy have come to unhappy ends. The cautious can be tempted to say: better the devil you know.

Yet the 'devil' side of liberal global democracy can be dangerous also, as inter alia the history of imperialism has demonstrated. Moreover, so much in today's global world is steeped in uncertainty: cultural, ecological, economic, political, and psychological. Why not accept a bit more uncertainty with new approaches to global democracy? After all, liberal thinking has been so deficient in bringing people's power to the global politics of climate change, health pandemics, financial instability, Internet communications, migration crises, and so on. Giving post-liberal ideas a chance could be a matter of life and death for democracy itself.

No doubt sceptics will reply that the challenges just reviewed are inherently insurmountable, while doomsayers will say that only planetary catastrophe-for example, with ecological collapse, capitalist disintegration, or another world war-can open space for veritable transformation of global politics. Certainly, the construction of post-liberal global democracy does not flow automatically; however, a modest dose of optimism is also historically warranted. Recall that the 'commonsense' of earlier days dismissed universal suffrage, decolonisation, welfare states, and global governance as impossibilities. Tomorrow may prove today's 'realists' to be anything but!

Acknowledgements My huge gratitude for 6 years of inspirational collaboration and feedback goes to co-conveners of the Building Global Democracy (BGD) programme: Diana Brydon, Jessica Byron, Alla Glinchikova, Sitiveni Halapua, Heba Raouf Ezzat, Anand Kumar, Moema de Miranda, Alfred Nhema, and Peng Zongchao. Enormous thanks also go to the Ford Foundation (Grant No. 1080-0271) for generous core funding of the BGD initiative. Supplementary BGD project support was gratefully received from the Centre for Global Cooperation Research (University of Duisburg-Essen), the Centre for Governance Innovation (University of Pretoria), the Gothenburg Centre of Globalisation and Development (University of Gothenburg), Oxfam Novib, and World Vision Australia.

Open Access This article is distributed under the terms of the Creative Commons Attribution 4.0 International License (http://creativecommons.org/licenses/by/4.0/), which permits unrestricted use, distribution, and reproduction in any medium, provided you give appropriate credit to the original author(s) and the source, provide a link to the Creative Commons license, and indicate if changes were made.

\section{References}

Adamovsky, Ezequiel. 2012. Democracy and Global Redistribution: Reflections on Argentine Struggles against Neoliberalism. Paper for the Structural Redistribution for Global Democracy Project.

Amoore, Louise (ed.). 2005. The Global Resistance Reader. Abingdon: Routledge.

Anievas, Alexander, et al. (eds). 2015. Race and Racism in International Relations: Confronting the Global Colour Line. Abingdon: Routledge.

Archibugi, Daniele, et al. (eds.). 2012. Global Democracy: Normative and Empirical Perspectives. Cambridge: Cambridge University Press.

Ata, Sam, and Sitiveni Halapua. 2011. Learning through Truth and Reconciliation Processes in the Solomon Islands. Paper for the Learning for Global Democracy Project.

Ayish, Muhammad I. 2011. Satellite Television and Global Democratic Consciousness. Paper for the Learning for Global Democracy Project.

Bäckstrand, Karin. 2006. Democratizing Global Environmental Governance? Stakeholder Democracy after the World Summit on Sustainable Development. European Journal of International Relations 12(4): 467-498. 
Bedirhanoğlu, Pınar. 2016. Corruption of Anti-Corruption: Deconstructing Neoliberal Good Governance. In New Rules for Global Justice: Structural Redistribution in the Global Economy, ed. Jan Aart Scholte, Lorenzo Fioramonti, and Alfred Nhema. London: Rowman \& Littlefield International.

Bohman, James. 2007. Democracy across Borders: From Dêmos to Dêmoi. Cambridge, MA: MIT Press.

Bourdieu, Pierre, and Loic J.D. Wacquant. 1992. An Invitation to Reflexive Sociology. Chicago: University of Chicago Press.

Bradlow, Benjamin, and Rose Molokoane. 2011. Empowering the Urban Poor in Global Politics. Paper for the Empowering the Margins in Global Politics Project.

Bray, Daniel, and Steven Slaughter. 2015. Global Democratic Theory: A Critical Introduction. Cambridge: Polity.

Brown, L. David. (ed.) (2001) Practice-Research Engagement and Civil Society in a Globalizing World. Cambridge, MA: Hauser Center for Nonprofit Organizations. http://siteresources.worldbank.org/ INTPCENG/1220158-1118058516777/20526704/D87D671E-CDE9-11D5-857B0002A56B5CB F.pdf. Accessed 13 May 2019

Bu, Wei. 2011. Including Children in Global Politics. Paper for the Empowering the Margins in Global Politics Project.

Cabrera, Luis. 2010. The Practice of Global Citizenship. Cambridge: Cambridge University Press.

Campbell Barr, Epsy. 2011. Political Empowerment of Afro-Descendent Women. Paper for the Empowering the Margins in Global Politics Project.

Cordeiro Ferreira, Andrey, and João Pacheco de Oliveira Filho. 2011. Empowering Indigenous Peoples in Global Politics: Experiences from Brazil. Paper for the Empowering the Margins in Global Politics Project.

Crédit Suisse. 2017. Global Wealth Report 2017. Zürich: Crédit Suisse Research Institute.

Dahl, Robert A. 1999. Can International Organizations Be Democratic? A Skeptic's View. In Democracy's Edges, ed. I. Shapiro and C. Hacker-Cordón, 19-36. Cambridge: Cambridge University Press.

De Sousa Santos, Boaventura (ed.). 2007. Cognitive Justice in a Global World: Prudent Knowledges for a Decent Life. Lanham: Lexington.

De Wilde, Jaap. 2011. The Mirage of Global Democracy. European Review 19(1): 5-18.

Della Porta, Donatella, and Nicole Doerr. 2011. Civic Learning in Social Forums: Democratic Education through Global Protest. Paper for the Learning for Global Democracy Project.

Dryzek, John S. 2006. Deliberative Global Politics. Cambridge: Polity.

El-Ghazali, Abdel Hamid Hasan. 2001. The Way to the Revival of the Muslim Ummah. Cairo: Al-Falah Foundation.

Eschle, Catherine. 2001. Global Democracy, Social Movements, and Feminism. Boulder: Westview.

Fedatova, Valentina. 2016. Structural Redistribution through Global Social Democracy. In New Rules for Global Justice: Structural Redistribution in the Global Economy, ed. Jan Aart Scholte, Lorenzo Fioramonti, and Alfred Nhema. London: Rowman \& Littlefield International.

Ford-Smith, Honor. 2011. Letters from the Dead: Pedagogies of Performance and Transnational Democracy. Paper for the Learning for Global Democracy Project.

Fukuyama, Francis. 1992. The End of History and the Last Man. New York: Free Press.

Geist, Michael. 2012. The Internet Fights Back. Paper for the Structural Redistribution for Global Democracy Project.

Ghani, Gairuzazmi M. 2011. Including Islamic Finance in the Global Economy. Paper for the Empowering the Margins in Global Politics Project.

Giddens, Anthony. 1984. The Constitution of Society: Outline of the Theory of Structuration. Cambridge: Polity.

Gleckman, Harris. 2018. Multistakeholder Governance and Democracy: A Global Challenge. Abingdon: Routledge.

Gudynas, Eduardo. 2011. Buen vivir Germinados alternativas al desarrollo. Quito: ALAI.

Guerrero, Dorothy Grace. 2016. Global Redistribution through Climate Justice. In New Rules for Global Justice: Structural Redistribution in the Global Economy, ed. Jan Aart Scholte, Lorenzo Fioramonti, and Alfred Nhema. London: Rowman \& Littlefield International.

Halapua, Sitiveni, and Peau Halapua. 2010. Global Democracy as Talanoa: A Pacific Perspective. Paper for the Conceptualising Global Democracy Project.

Hall, Nina, and Inge Kaul. 2016. Financing Global Public Goods: The Case for a Currency Transaction Levy. In New Rules for Global Justice: Structural Redistribution in the Global Economy, ed. Jan Aart Scholte, Lorenzo Fioramonti, and Alfred Nhema. London: Rowman \& Littlefield International.

Hallström, Kristina T., and Magnus Boström. 2010. Transnational Multi-Stakeholder Standardization. Cheltenham: Elgar. 
Held, David, and Heikki Patomäki. 2006. Problems of Global Democracy: A Dialogue. Theory, Culture \& Society 23(5): 115-133.

Keohane, Robert O., et al. 2009. Democracy-Enhancing Multilateralism. International Organization 63(1): $1-31$.

Kumar, Vivek. 2011. A Question of Caste: Including Dalits in Global Politics. Paper for the Empowering the Margins in Global Politics Project.

Kwa, Aileen. 2012. A Trading System that Serves People and Development. Paper for the Structural Redistribution for Global Democracy Project.

Lander, Edgardo. 2010. The Decolonisation of Global Democracy. Paper for the Conceptualising Global Democracy Project.

Liu, Taoxiong, and Mendang Huang. 2016. An Alternative Global Money: Special Drawing Rights or Bitcoin? In New Rules for Global Justice: Structural Redistribution in the Global Economy, ed. Jan Aart Scholte, Lorenzo Fioramonti, and Alfred Nhema. London: Rowman \& Littlefield International.

Maldonado, Maria Tereza. 2009. Florestania: A cidadania dos povos da floresta. 6th ed. São Paulo: Saraiva.

McCall, L. 2005. The Complexity of Intersectionality. Signs 30(3): 1771-1800.

McKeon, Nora. 2011. Empowering Peasants in Global Politics. Paper for the Empowering the Margins in Global Politics Project.

Milanovic, Branko. 2009. Global Inequality Recalculated. Washington: World Bank Policy Research Working Paper 5061.

Miller, David. 1995. On Nationality. Oxford: Oxford University Press.

Mohammed, Patricia. 2010. Gender Politics and Global Democracy: Insights from the Caribbean. Paper for the Conceptualising Global Democracy Project.

Moravcsik, Andrew. 2004. Is There a 'Democratic Deficit' in World Politics? A Framework for Analysis. Government and Opposition 39(2): 336-363.

Mostafa, Nadia. 2010. Towards an Islamic Perspective on Global Democracy. Paper for the Conceptualising Global Democracy Project.

Mullings, Beverley, and Alissa Trotz. 2016. Engaging the Diasporas: An Alternative Paradigm from the Caribbean. In New Rules for Global Justice: Structural Redistribution in the Global Economy, ed. Jan Aart Scholte, Lorenzo Fioramonti, and Alfred Nhema. London: Rowman \& Littlefield International.

Musamba, Charity. 2015. Cultural Diversity and Democratic Global Cooperation: A Perspective from Africa. In Global Cooperation through Cultural Diversity: Remaking Democracy?, ed. Jan Aart Scholte. Duisburg: Centre for Global Cooperation Research (Global Dialogues 8).

Mwatha, Regina Gathoni. 2010. Gender Empowerment and Global Democracy: Experiences from Kenya. Paper for the Conceptualising Global Democracy Project.

Nizamova, Liliya. 2011. Supranational Empowerment of National Minorities: Tatars and Tatarstan in Global Politics. Paper for the Including the Excluded in Global Politics Project.

Oommen, T. K. 2011. From Hierarchy to Equality in Global Studies. Paper for the Learning for Global Democracy Project.

Patomäki, Heikki. 2011. Towards Global Political Parties. Ethics \& Global Politics 4(2): 81-102.

Posner, Paul L. 2009. The Pracademic: An Agenda for Re-Engaging Practitioners and Academics. Public Budgeting and Finance 29 (1): 12-26.

Raymond, Mark, and Laura DeNardis. 2015. Multistakeholderism: Anatomy of an Inchoate Global Institution. International Theory 7(3): 572-616.

Reason, Peter, and Hilary Bradbury (eds.). 2008. The SAGE Handbook of Action Research: Participative Inquiry and Practice. London: SAGE.

Rio. 2011 Workshop evaluation form completed by a participant in the Empowering the Margins in Global Politics project, April 2011.

Scheper-Hughes, N. 1995. The Primacy of the Ethical: Propositions for a Militant Anthropology. Current Anthropology 36(3): 409-420.

Scholte, Jan Aart. 1993. International Relations of Social Change. Buckingham: Open University Press.

Scholte, Jan Aart. 2004. Democratizing the Global Economy: The Role of Civil Society. Coventry: Centre for the Study of Globalisation and Regionalisation.

Scholte, Jan Aart. 2005. Globalization: A Critical Introduction. 2nd ed. Basingstoke: Palgrave Macmillan.

Scholte, Jan Aart. 2014. Reinventing Global Democracy. European Journal of International Relations 20(1): 3-28. 
Scholte, Jan Aart (ed.). 2015. Global Cooperation through Cultural Diversity: Remaking Democracy?. Duisburg: Centre for Global Cooperation Research (Global Dialogues 8).

Scholte, Jan Aart. 2019. Democracy. In Oxford Handbook of Global Studies, ed. Mark Juergensmeyer, Saskia Sassen, and Manfred Steger, 431-454. Oxford: Oxford University Press.

Scholte, Jan Aart (ed.) (forthcoming) Global Voices, Global Democracy (in preparation).

Scholte, Jan Aart, Lorenzo Fioramonti, and Alfred Nhema (eds.). 2016. New Rules for Global Justice: Structural Redistribution in the Global Economy. London: Rowman \& Littlefield International.

Shiva, Vandana. 2005. Earth Democracy. Boston, MA: South End.

Sichone, Owen. 2011. Learning Globalism: Opposing Xenophobia in Post-Apartheid South Africa. Paper for the Learning for Global Democracy Project.

Singh, Ramjee. 2010. A Plea for Global Democracy. Paper for the Conceptualising Global Democracy Project.

Smith, Jackie, et al. 2007. The World Social Forums and the Challenge of Global Democracy. Boulder: Paradigm.

Smith, Will, and James Brassett. 2008. Deliberation and Global Governance: Liberal, Cosmopolitan, and Critical Perspectives. Ethics \& International Affairs 22(1): 69-92.

Sohng, Sue S.L. 1997. Participatory Research Approaches: Some Key Concepts. Participatory Research and Development for Sustainable Agriculture and Natural Resource Management: A Sourcebook, 62-64. Ottawa: International Development Research Centre.

Stevenson, Hayley, and John Dryzek. 2014. Democratizing Global Climate Governance. Cambridge: Cambridge University Press.

Stewart-Harawira, Makere. 2011. Indigenous Ways of Being and Post-Imperial Global Learning. Paper for the Learning for Global Democracy Project.

Strauss, Andrew L. 2005. Taking Democracy Global: Assessing the Benefits and Challenges of a Global Parliamentary Assembly. London: One World Trust.

Tandon, Yash. 2016. Rethinking Global Investment. In New Rules for Global Justice: Structural Redistribution in the Global Economy, ed. Jan Aart Scholte, Lorenzo Fioramonti, and Alfred Nhema. London: Rowman \& Littlefield International.

Tännsjö, Torbjörn. 2008. Global Democracy: The Case for a World Government. Edinburgh: Edinburgh University Press.

Vainer, Carlos, and Flávia B. Vieira. 2011. From the Valleys to Global Forums: Learning for Action in Rural Movements of Brazil. Paper for the Learning for Global Democracy Project.

Vance, Kim. 2011. Raising Our Voices: Opening Global Spaces for Sexual and Gender Minorities. Paper for the Including the Excluded in Global Politics Project.

Vartanova, Elena. 2011. Digital Citizens and Media Literacy for Global Democracy. Paper for the Learning for Global Democracy Project.

Weber, Heloise. 2016. From Land Grabs to Food Sovereignty. In New Rules for Global Justice: Structural Redistribution in the Global Economy, ed. Jan Aart Scholte, Lorenzo Fioramonti, and Alfred Nhema. London: Rowman \& Littlefield International.

Williams, Melissa. 2010. Linking Fates Together: Democratic Imaginaries and Global Public Space. Paper for the Conceptualising Global Democracy Project.

Xu, Jiajung, Ma Ben, and Peng Zongchao. 2010. Cooperative-Harmonious Global Democracy from the Perspective of Chinese Culture. Paper for the Conceptualising Global Democracy Project.

Yang, Xuedong. 2014. Bottom-Line Thinking and Transculturalism. Paper for the Global Democracy through Cultural Diversity Project.

Yuval-Davis, N. 2011. The Politics of Belonging: Intersectional Contestations. London: Sage.

Zhu, Jiangang. 2011. Global-Local Learning in Civil Society: The Huangpu NGO Capacity Building Programme. Paper for the Learning for Global Democracy Project.

Jan Aart Scholte is Professor of Peace and Development in the School of Global Studies at the University of Gothenburg, as well as Co-Director of the Centre for Global Cooperation Research at the University of Duisburg-Essen. Scholte's research spans globalization, global governance, civil society in global politics, legitimacy in global governance, global democracy, and methodologies of global studies. Latest book (co-edited with Jonas Tallberg and Karin Bäckstrand) is Legitimacy in Global Governance: Sources, Processes, and Consequences (Oxford University Press, 2018). 